that the Ngeumba tribe is divided into " castes" and "bloods" as well as kins and phratries. The Ngeumba, whom another writer seems to have termed Nyamba, are near neighbours of the Euahlayi on the Narran River, and the names for the "blood" divisions in the Ngeumba tribe are virtually identical with those given as phratry names by Mrs. Langloh Parker for the Euahlayi. That being so, we have the choice of three theories:- (I) that both authors are correct; (2) that Mr. Mathews has confused two tribes; or (3) that Mrs. Parker's information is incomplete. In view of the fact that she resided twenty years among them and gained the full confidence of the Euahlayi, the latter seems improbable; we are therefore left to choose between a superposition of organisations or a confusion created by Mr. Mathews. He does not work out how the "blood" organisation affects the ordinary social organisation.

The "castes" are stated to have reference to the manner of camping and to denote the shade of various parts of a tree; our confidence in this explanation is not increased by the discovery that one of the words, nurai, is the ordinary name for the black snake totem in two or three adjoining tribes. It is to be hoped that some anthropologist of reputation will turn his attention to the tribe. If Mr. Mathews's information turns out to be correct, he will have done something towards establishing his reputation.

N. W. T.

\section{THE BREEDING INDUSTRY.}

The Breeding Industry. By Walter Heape, F.R.S. Pp. xii $+{ }^{54}$. (Cambridge: University Press, I906.) Price 2s. 6d, net.

THE author of the present volume has long been 1 distinguished for his investigations in vertebrate embryology and the physiology of vertebrate reproduction. He has also paid considerable attention to the practical aspects of the subject, in so far as they concern the methods adopted by the animal breeder and the needs of the breeding industry. In the light of the special knowledge and experience which he has thus gained, Mr. Heape has become firmly convinced that the breeder will derive "inestimable advantage from the right application of science to the industry with which he is concerned," while it is no less his strong belief "that the field of scientific biology will be broadened, the number of workers therein increased, and the means available for their work augmented, as the result of ... more intimate relations between scientific and practical biologists." Those who read this volume, and all others who are familiar with the nature of the questions discussed therein, can have little difficulty in realising that $\mathrm{Mr}$. Heape is right.

The first chapter, which is introductory in character, deals with the present position of the breeding industry in our own country. The scientific man and the breeder are too frequently antagonistic, and tend to distrust one another. This antagonism, which NO. I909, vOL. 74] is quite unnecessary, is as much the fault of the man of science as of the practical man, and it is to be partly ascribed to the unsympathetic attitude of the former towards many of the facts and problems of practical breeding, as well as to the general neglect by professed biologists of that wide field of investigation comprised within the physiology of reproduction. All this is pointed out in somewhat different language by the author, who lays great stress on the enormous advantages to be gained by the introduction of scientific method into the industry of breeding, just as it has proved invaluable to other industries.

The second chapter consists of a concise, clear, and eminently business-like calculation of the value of the breeding industry to the country. As a result of this calculation Mr. Heape arrives at the truly remarkable conclusion that the total sum invested in live-stock in the British Islands is scarcely less than 450,000,oool. - an estimate which does not appear to err on the side of excess. Added to this the capital invested in various accessories-vehicles, machinery, housing, \&c.-the total becomes still more gigantic. And yet, in the words quoted from Mr. Bateson, the breeding industry is one "to which science has never yet been applied."

In a further chapter the author deals with the nature of the work required for the advancement of the breeding industry. This is comprised under three heads-(I) the keeping of records, (2) the carrying on of research, and (3) the work of administration-all of which are shown to be of the utmost importance. Under the heading of research the author alludes to the special nature of certain of the problems which require elucidation, and particularly those relating to the physiology of the generative system. He might have added that proper facilities for carrying out this kind of research are at present practically non-existent. Such as do exist are due almost entirely to private enterprise and generosity. In order to conduct on any considerable scale investigations upon questions involving the maintenance of animals under reasonably natural conditions and for prolonged periods of time, as well as for the study of the phenomena of inheritance and variation, the creation of some sort of experiment station or biological farm has become a matter of urgent necessity. For carrying on the work of administration Mr. Heape advocates the institution of a State department of animal industry, which would form a section of a new Board of Agriculture.

In the final chapter the management and work of the present Board of Agriculture are discussed, and it is pointed out that there is a want of confidence in its methods and an inadequacy about its organisation which compare unfavourably with those of the corresponding American department.

Mr. Heape's book is well calculated to arouse public interest, for the problem with which it deals is the concern, not only of the man of science, but of all who have regard for the welfare of one of the greatest industries of the nation.

Francis H. A. Marshall. 